\title{
PENGEMBANGAN MANAJEMEN PENYIARAN WALISONGO TV
}

\author{
Nur Cahyo Hendro Wibowo \\ Jurusan Komunikasi dan Penyiaran Islam UIN Walisongo \\ nur_cahyo@walisongo.ac.id
}

\begin{abstract}
$T$

elevision is the media most widely consumed by the people of the world and especially Indonesia, with conditions like this the influence of television to be very large on the mindset and patterns of public attitudes. Faculty of Da'wah and Communications UIN Walisongo as an institution that is responsible for the success of Islamic propagation in Indonesia is very appropriate to use television as one of his da'wah media. The management of broadcast television is classified into modern management because all activities in preparing and producing broadcast can not be separated from computer technology. computers have an enormous influence in speeding up a product, with collaboration between software will create new innovation results in broadcast television. The programs that will be presented must be well managed, by conducting scheduling time management of the expected broadcast programs that will be served can be anticipated as early as possible. The production process of television broadcasting must be done before the program is aired. Through the process of film editing in which there is a payload of information a television program can be produced. TV broadcasting program is integrated with Walisongo TV broadcast management information system software.
\end{abstract}

Keywords : Broadcast management, Television, Technology

\begin{abstract}
ABSTRAK
7 elevisi adalah media yang paling luas dikonsumsi oleh masyarakat dunia dan khususnya Indonesia, dengan kondisi seperti ini pengaruh televisi menjadi sangat besar terhadap pola pikir maupun pola sikap masyarakat. Fakultas Dakwah dan Komunikasi UIN Walisongo sebagai sebuah institusi yang ikut bertanggung jawab atas berhasilnya dakwah Islam di Indonesia sangatlah tepat untuk menggunakan televisi sebagai salah satu media dakwahnya. Managemen siaran televisi digolongkan kedalam manajemen modern karena semua aktivitas dalam mempersiapkan dan memproduksi siaran tidak bisa lepas dari teknologi komputer. komputer mempunyai pengaruh yang sangat besar dalam mempercepat menghasilkan sebuah produk, dengan kolaborasi antar software akan tercipta hasil inovasi baru dalam siaran televisi. Program-program yang akan disajikan harus dikelola dengan baik, dengan melakukan managemen penjadwalan waktu siaran diharapkan program-program yang akan ditayangkan dapat diantisipasi sedini mungkin. Proses produksi siaran televisi harus dikerjakan sebelum program tersebut ditayangkan. Melalui proses editing film yang didalamnya terdapat muatan informasi sebuah program tayangan televisi dapat dihasilkan. Program siaran televisi tersebut diintegrasikan dengan software sistem informasi manajemen siaran Walisongo TV.
\end{abstract}

Kata Kunci : Manajemen penyiaran, televisi, Teknologi 


\section{PENDAHULUAN}

Televisi adalah media yang paling luas dikonsumsi oleh masyarakat dunia dan khususnya Indonesia yang jauh dari budaya baca tulis. Media ini, sebagai media audio-visual tidak membebani banyak syarat bagi yang ingin menikmatinya. Untuk masyarakat Indonesia, yang notabene lebih dekat dengan budaya lisan, media televisi lebih akrab, sehingga pengaruh televisi jauh lebih besar dari pada media massa lain. Tak dapat disangkal dalam dekade baru ini televisi adalah produk canggih paling populer dan amat memasyarakat. Sejak ditemukan oleh pria asal Skotlandia, John Logie Baird pada tahun 1926 dan disempurnakan oleh pria asal AS keturunan Rusia, Vladimir Zworykin. Televisi menjadi satu-satunya perlengkapan rumah tangga yang dimiliki setiap keluarga betapapun miskinnya keluarga itu, seolah-olah televisi adalah sesuatu yang wajib dimiliki. Perkembangan keberadaannya jauh melampaui media-media massa lain. Seperti media koran, majalah, dan apalagi buku.

Mencermati perkembangan penyiaran televisi nasional, kadang kita menjadi merasa sangat cemas. Betapa besar dan kuat pengaruh media yang satu ini terhadap manusia. Tayangan-tayangan hebatnya, setiap saat memborbardir pikiran dan kesadaran kita. Sayangnya, tidak semua pemilik TV Broadcasting memiliki kehati-hatian dalam memanfaatkan 'senjata yang mematikan' ini. Saat ini, TV secara umum bukan menggambarkan wajah Indonesia, tetapi lebih cenderung merupakan wajah segelintir masyarakat eksklusif (selebriti) yang secara kuat mempengaruhi dan membentuk pribadi-pribadi penonton Indonesia. Sungguh suatu ironi. Banyak acara-acara di televisi saat ini yang sudah bukan merupakan media untuk mendidik generasi yang baik tetapi hanya sekedar menyajikan tontonan yang banyak merusak mental generasi muda. Anehnya banyak yang tidak mau peduli dengan keadaan saat ini, bahkan umat Islam sendiri juga tidak mau peduli terhadap tontonan-tontonan televisi yang sangat jauh dari tuntunan agama. Sekitar 90\% penduduk Indonesia adalah Muslim.

Fakultas Dakwah dan komunikasi UIN Walisongo sebagai sebuah institusi yang ikut bertanggung jawab atas berhasilnya dakwah Islam di Indonesia sangatlah tepat untuk menggunakan televisi sebagai salah satu media dakwahnya. Dengan media televisi diharapkan dakwah akan lebih mudah merasuk dalam jiwa masyarakat untuk kemudian mempengaruhi perilaku masyarakat sesuai dengan ajaran Islam. Adanya televisi di lingkungan Fakultas Dakwah juga sekaligus bisa dijadikan sebagai laboratorium tempat mahasiswa mempraktekkan teori-teori yang didapat dalam kuliah mereka. Lebih jauh, televisi juga bisa dijadikan sarana untuk memperkenalkan UIN Walisongo kepada masyarakat, mengkomunikasikan program -program yang dilakukan dan juga sebagai sarana untuk menarik minat para calon mahasiswa untuk memilih UIN Walisongo sebagai tempat menempuh pendidikan.

Keberadaan televisi komunitas di Fakultas Dakwah sudah mulai dirintis pada tahun 2012 ini. Televisi komunitas ini bernama Walisongo TV. Sebagai sebuah stasiun televisi yang baru dirintis, banyak aspek yang perlu dipersiapkan 
dengan baik. Salah satu di antaranya adalah manajemen penjadwalan siaran. Manajemen penjadwalan siaran harus dibuat dengan baik demi keberlanjutan penyiaran Walisongo TV. Mengingat pentingnya manajemen penjadwalan siaran ini, kami bermaksud merancang sebuah software manajemen penjadwalan yang terintegrasi dengan programprogram siaran yang dapat dikelola dengan mudah menggunakan komputer.

Mengelola media penyiaran pada dasarnya adalah mengelola manusia. Keberhasilan media penyiaran sejatinya ditopang oleh kreatifitas manusia yang bekerja pada tiga pilar utama yang merupakan fungsi vital yang dimiliki setiap media penyiaran yaitu teknik, program dan pemasaran. Keberhasilan media penyiaran bergantung pada bagaimana kualitas orang-orang yang bekerja pada ketiga bidang tersebut. Namun demikian, kualitas manusia saja tidak cukup jika tidak disertai dengan kemampuan pimpinan media penyiaran yang bersangkutan dalam mengelola sumberdaya manusia yang ada. Karena alasan inilah manajemen yang baik mutlak diperlukan pada media penyiaran.

Mengelola suatu media penyiaran memberikan tantangan yang tidak mudah kepada pengelolanya. Tantangan yang harus dihadapi manajemen media penyiaran disebabkan dua hal. Pertama, sebagaimana perusahaan lainnya, media penyiaran dalam kegiatan operasionalnya harus dapat memenuhi harapan pemilik dan pemegang saham untuk menjadi perusahaan yang sehat dan mampu menghasilkan keuntungan. Namun di pihak lain, sebagai tantangan kedua, media penyiaran harus mampu memenuhi kepentingan masyarakat (komunitas) di mana media bersangkutan berada, sebagai ketentuan yang harus dipenuhi ketika media penyiaran yang bersangkutan menerima izin siaran (lisensi) yang diberikan negara.

Dengan demikian upaya untuk menyeimbangkan antara memenuhi kepentingan pemilik dan kepentingan masyarakat memberikan tantangan tersendiri kepada pihak manajemen media penyiaran. Media penyiaran pada dasarnya harus mampu melaksanakan berbagai fungsi yaitu antara lain fungsinya sebagai media untuk beriklan, media hiburan, media informasi dan media pelayanan.untuk mampu melaksanakan seluruh fungsi tersebut sekaligus dapat memenuhi kepentingan pemasang iklan, audien serta pemilik dan karyawan merupakan tantangan tersendiri bagi manajemen.

Walisongo TV sebagai sebuah media penyiaran televisi, tidak selamanya akan menjadi lembaga penyiaran komunitas. Pada masa yang akan datang, Walisongo TV berbenah untuk bisa menjadi stasiun televisi di Indonesia yang disegani, terutama di wilayah Jawa Tengah. Untuk mencapai hal itu tentu tidaklah mudah. Dibutuhkan manajemen yang baik agar tujuan itu bisa terwujud. Untuk itu dibuatlah konsep pengembangan manajemen dan system informasi agar walisongo TV dapat berkembang dengan baik.

\section{Perencanaan Program Walisongo TV}

Merencanakan program siaran secara umum dilakukan untuk mengatur alokasi waktu dan materi siaran dalam waktu sehari, seminggu, hingga setahun. Bagian program bertanggungjawab untuk mendapatkan program serta menentukan waktu penayangan program. Menurut 
Morissan (2008:247), ada dua hal yang harus diputuskan dalam merencanakan program, yaitu: 1) keputusan mengenai target audien, dan 2) keputusan mengenai target pendapatan.

Target audien, diarahkan bagaimana program televisi dapat menyeleksi dan menjadwalkan penayangan suatu program yang dapat menarik sebanyak mungkin penonton yang ada pada waktu tertentu. Perencanaan program harus melakukan riset terhadap selera audien sebelum membeli suatu program. Program yang sukses secara umum harganya pasti mahal, namun tak ada jaminan program itu akan sukses di tempat lain. Pengelola program siar yang baik harus mengetahui apa yang menarik untuk kelompok-kelompok yang berbeda di kalangan masyarakat.

Target pendapatan yang dapat diterima dari program penyiaran yang ditayangkan diusahakan sesuai dengan target pendapatan yang sudah ditetapkan. Bagian program selalu berkonsultasi terlebih dahulu dengan bagian pemasaran sebelum merencanakan dan memilih program. Hal ini dilakukan karena bagian pemasaranlah yang akan memasarkan program kepada pemasang iklan, sehingga diperoleh keuntungan secara finansial maupun prospek peringkat acara (rating) dari hasil kegiatan penyiaran suatu program baru. Dampak yang lebih baik lagi terhadap nilai saham akan meningkat jika stasiun penyiaran sudah go public.

\section{Tujuan program Walisongo TV}

Secara umum tujuan program walisongo TV adalah untuk menarik dan mendapatkan sebanyak mungkin audien guna menarik pemasang iklan. Adapun secara khusus tujuan penayangan suatu program adalah :1) mendapatkan sebanyak mungkin audien, 2) sesuai dengan target audien tertentu, 3) prestise, 4) penghargaan, 5) kepentingan publik.

Mendapatkan sebanyak mungkin audien. Tujuan dari kebanyakan program siaran televisi adalah untuk mendapatkan audien sebanyak-banyaknya. Karena ada hubungannya dengan pemasangan siaran iklan yang banyak mengeluarkan dana untuk memasarkan dan mempromosikan produk mereka kepada audien. Semakin banyak audien yang melihat program siaran semakin banyak audien yang kengenal produknya dan besar kemungkinan akan terpengaruh untuk membeli produk tersebut. Sehingga keuntungan pihak pemasang iklan akan bertambah dan akan menambah frekwensi iklan pada program siaran.

Target audien tertentu. Pemasang iklan akan lebih tertarik pada audien tertentu atau pada audien yang tidak terlalu besar, misalnya kalangan pria papan atas menjadi incaran perusahaan mobil mewah. Program yang dikhususkan pada audien tertentu dengan daya tarik yang terbatas sebaiknya didasarkan jenis kelamin , umur, profesi, dan lain-lain.

Prestise. Ada stasiun televisi yang menyiarkan programnya dengan tujuan untuk mendapatkan prestise atau pengakuan dari pihak lain. Misalnya filmfilm yang berkualitas dan mendapatkan penghargaan. Secara komersial acara tersebut tidak begitu kuat untuk menarik audien dalam jumlah besar namun adakalanya stasiun penyiaran menayangkan acara tersebut untuk mendapatkan pengakuan dari poihak lain dan meningkatkan citranya kepada publik. 
Penghargaan. Perlunya membuat program acara dengan tujuan untuk memenangkan suatu penghargaan sehingga meningkatkan statusnya. Stasiun televisi yang memproduksi program yang berkualitas baik pada umumnya ingin mendapatkan suatu penghargaan dan pengakuan dari publik atas karyanya. Penghargaan itu juga bisa menjadi ajang promosi gratis bagi audien yang menjadi ertarik menontonnya.

Kepentingan publik. Program acara ini dibuat untuk memenuhi kebutuhan dan kepentingan publik di lingkungan stasiun televisi berada. Tanggungjawab stasiun untuk memenuhi kebutuhan audien di sekitar lingkungannya. Setiap daerah memiliki keunikan sendiri-sendiri sesuai dengan kultur budayanya. Produksi program ini bisa menjadi kegiatan sosial yang tidak menguntungkan secara komersial tetapi mampu memenuhi kebutuhan publik.

\section{Walisongo TV sebagai TV Komunitas}

Kemunculan televisi komunitas di Indonesia tidak terlepas dari proses kritik terhadap keberadaan berbagai televisi di Indonesia itu sendiri, dimana stasiun televisi sebagai media massif yang efektif ternyata tidak mencerahkan kehidupan masyarakat. Sebagian besar program siaran yang ditayangkan tidak mendidik dan jauh dari realitas kehidupan sosial masyarakat kita. Sinetron misalnya, selalu mengetengahkan kemewahan yang tidak dipunyai masyarakat kebanyakan. Televisi menjadi media dominan, bukan saja bagi individu untuk memperoleh gambaran dan citra realitas sosial, tetapi juga bagi masyarakat dan kelompok secara kolektif. Media menyuguhkan nilai-nilai dan penilaian normatif yang dibaurkan dengan berita dan hiburan. (Mc Quail, 1996:3)

Perkembangan media sebenarnya diikuti oleh tuntutan kepada media untuk memiliki suatu tanggungjawab sosial. Kebebasan yang dimiliki media perlu disertai tanggungjawab sosial dan dan kecenderungan berorientasi pada kepentingan umum, baik secara individual maupun kelompok. (Wibowo, 1997: 58). Namun pada kenyataannya, media penyiaran (khususnya televisi swasta) menafikkan tanggungjawab sosialnya karena tuntutan bisnis untuk meraih keuntungan yan sebesar-besarnya dengan rating televisi (ukuran banyak pemirsa yang menonton sebuah acara di televisi pada satu waktu) menjadi dewa dan barometer bagi industri televisi tanpa melihat dampak yang bisa ditimbulkannya. Televisi komunitaslah yang kemudian dianggap sebagai media yang memiliki tanggungjawab sosial terhadap masyarakatnya (khalayak pemirsa). Media komunitas dirasa tepat sebagai pilihan media yang berpihak pada kepentingan masyarakat.

Televisi komunitas lahir menjadi tonggak baru dalam dunia penyiaran di Indonesia. Media komunitas ini hadir sebagai media alternatif yang mengusung keberagaman kepemilikan (diversity of ownership), yang juga mendorong adanya keberagaman isi (diversity of content) dalam program-program siaran karena melayani komunitasnya yang juga beragam. Karena keberagaman kepemilikan itulah, masyarakat bisa melakukan kontrol sendiri (self controlling) terhadap isi siaran. Pengelola televisi komunitas tidak bisa sewenangwenang menayangkan program siaran 
yang tidak sesuai dengan nilai, aturan, maupun budaya lokal.(Budhi, 2008).

\section{Sumber Program Walisongo TV}

Program yang disiarkan Walisongo TV ke depan harus mampu menyediakan puluhan jam siaran setiap minggunya dan ratusan jam setiap bulannya. Maka dari itu diperlukan program untuk mengisi acara pada waktu yang tersedia. Sumber program yang akan disiarkan bisa dari produksi sendiri, kerja sama dengan jaringan stasiun lokal maupun nasional, rumah produksi, perusahaan film atau pemasang iklan.

Acara yang bisa diproduksi sendiri di studio biasanya jenis program informasi yang dilaksanakan oleh Departemen berita. Untuk itu sumber daya yang ada pada Departemen berita harus memiliki karyawan yang handal seperti reporter, juru kamera, presenter, editor, produser, hingga direktur pemberitaan yang mampu bekerja secara penuh menghasilkan informasi yang menarik untuk dinikmati audien. Produser dan direktur pemberitaan yang bertugas untuk menentukan beritaberita apa saja yang akan ditayangkan dan bagaimana urutan penayangannya.

Acara lain yang bisa diproduksi sendiri selain berita adalah acara hiburan baik drama maupun non drama. Program drama seperti sinetron dan film, sedangkan non drama adalah musik dan variety show. Produksinya menggunakan fasilitas yang tersedia dan dimiliki oleh stasiun Walisongo TV. Sebelum memproduksi dibutuhkan ide, gagasan baik dari internal maupun eksternal.

Program yang disiarkan melalui stasiun jaringan dengan televisi lokal atau daerah misalnya olah raga, hiburan, perbincangan, atau pemutaran kembali program yang pernah disiarkan. Acara tersebut bisa disiarkan karena berbagai pertimbangan berdasarkan efisiensi waktu, tenaga, maupun biaya. Sehingga produksinya diserahkan atau membeli rumah produksi lain yang dipercaya dan dipandang cakap memproduksi acara.

Hal yang sering dilakukan televisi lokal adalah memasuk program acara ke stasiun televisi lokal lainnya yang masih dalam kelompok usaha. Ada yang melakukan penayangan uji coba program baru untuk menguji daya tarik audien. Jika uji coba berhasil program itu akan diperluas siarannya bahkan bisa menjualnya ke berbagai stasiun televisi lokal lainnya. Jual beli program antar stasiun televisi termasuk diantaranya adalah program berita. Yang jelas kerjasama dengan stasiun televisi lokal lain sangat diperlukan untuk saling mendapatkan keuntungan dan kredibilitas dari audien.

Kerjasama yang harus dilakukan oleh stasiun televisi adalah dengan perusahaan film besar karena reputasinya yang tidak diragukan lagi. Pada umumnya perusahaan film besar memiliki tenaga kreatif secara khusus dibidangnya baik mengembangkan gagasan dan ide kreatif dibidangnya. Di samping itu juga dukungan dana yang kuat untuk memproduksi film. Bahkan tidak mudah terpengaruh oleh membengkaknya biaya produksi, perusahaan tetap dapat memenuhi komitmen untuk menyelesaikan program produksinya.

Adapun hal tentang pemasang iklan pada umumnya mempercayakan kepada rumah produksi untuk membuat program penayangan iklan sampai dengan penyiarannya. Program pemasang iklan dapat meminta apakah akan disiarkan 
untuk sekali tayang atau beberapa kali tergantung dari kesepakatan dengan pemilik stasiun televisi.

\section{Mempertahankan Konsistensi sebagai TV Komunitas}

Beberapa point penting yang yang harus dipertahankan jika masih ingin menjadi Walisongo TV sebagai TV komunitas, antara lain :

1) Community dimaknai citizen sehingga televisi komunitas mendiami geografis tertentu dan melayani komunitas dalam batasan geografis tersebut. Walisongo TV sebagai televisi komunitas diharapkan menyuarakan kepentingan dan kebutuhan warga dalam geografis tersebut, baik televisi berbasis warga, maupun televisi sekolah/kampus. Dalam hal ini walisongo TV harus dapat penyuarakan atau menyiarkan program-program diluar yang masih dalam batas radius siaran dan didalam kampus UIN Walisongo Semarang. Karenanya televisi komunitas tidak studio based, tetapi field based sehingga program siaran televisi komunitas tidak terhambat karena harus memenuhi "standard broadcasting" sebagaimana stasiun televisi swasta. Dengan menggunakan ruang public sebagai studio siaran bagi televisi komunitas, Walisongo TV harus dapat memenuhi keragaman isi (diversity of content) berdasar realitas kehidupan komunitasnya.

2) Isi siaran TV komunitas pada intinya membebaskan manusia dari keterasingan sebagai konsekuensi logis dari tekanan kapitalisme. Dalam kaitan ini, kehadiran media komunitas diharapkan dapat digunakan untuk menyambung kembali relasi sosial dalam lingkungan komunitas. Televisi komunitas sebagai community broadcasting menyuarakan suara akar rumput yang tidak terwadahi dalam media mainstream, sehingga ia mampu memberikan akses informasi pada masyarakat tentang kehidupan sehari-hari sekaligus mampu merangsang dialog sebagai bagian dari proses demokratisasi dan kontrol social serta memberikan lahan subur bagi budaya, identitas dan kearifan lokal. Program siaran yang baik dalam televisi komunitas adalah yang dekat dengan masyarakatnya, bahasanya dikenal, struktur bahasa dipahami, masalah digali dari masyarakat lokal, memakai musik dan gambar yang dikenal di daerah tersebut. Dengan ini, community broadcasting diharapkan membuat masyarakat lebih suka menonton karena mereka bisa menonton/mendengar sesuatu yang berhubungan dengan mereka sendiri.

3) Walisongo TV sebagai Televisi komunitas harus menjadi bagian dari proses membuat masyarakat berdaya. Harus ada proses pemberdayaan, bahkan jika itu diinisiasi oleh orang luar komunitasnya. Salah satu proses pemberdayaan yang bisa dilakukan adalah enjadikan televisi komunitas sebagai outlet bagi produk gerakan media literacy atau pendidikan melek media, sehingga masyarat bisa kritis terhadap isi siaran media.

4) Advokasi bagi pendirian dan perijinan televisi komunitas. Kendati telah 
terakomodasi dalam UU Penyiaran No 32 tahun 2002, keberadaan televisi komunitas masih membutuhkan bantuan advokasi, khususnya terkait dengan perijinan, alokasi frekuensi dan standart teknis bagi televisi komunitas. Advokasi juga diperlukan terkait dengan perkembangan teknologi digital dalam penyiaran yang akan diberlakukan oleh pemerintah bagi dunia penyiaran di Indonesia.

5) Televisi komunitas membutuhkan dedikasi karena tidak berorientasi mencari keuntungan. Modal utama bagi televisi komunitas adalah partisipasi masyarakat. Sehingga program siaran televisi komunitas merepresentasikan, merefleksikan sekaligus melibatkan komunitas, bukan perorangan. Televisi komunitas juga harus bertanggung jawab atas produk yang diproduksi.

6) Pengembangan jaringan. Untuk mewujudkan harapan sebagaimana terurai pada point diatas. Televisi komunitas perlu mengembangan jaringan kerjasama dengan berbagai pihak. Khususnya untuk penguatan kapasitas baik ketrampilan maupun pengetahuan bagi para pengelola televisi komunitas. Sebagai tindaklanjut dari kegiatan seminar dan workshop yang salah satunya diselenggarakan oleh FFTV-IKJ, pada bulan September 2007 diselenggarakan kegiatan training dan pertemuan televisi komunitas seIndonesia di Grabag TV, Grabag Magelang. Forum tesebut diikuti sejumlah pengelola televisi komunitas bebasis warga, maupun sekolah/kampus. Sebagian lainnya adalah lembaga swadaya masyarakat dan aktivis penyiaran. Pada forumforum petemuan televisi komunitas akan didapat suatu penguatan atau mendapatkan wawasan kedepan, yang salah satu wujud dari pertemuan tv komunitas adalah disepakati untuk membentuk kelompok kerja (Pokja) televisi komunitas Indonesia yang bertugas untuk; 1) Melakukan penguatan kapasitas bagi pengelola televisi komunitas, 2) Advokasi perijinan dan alokasi frekuensi bagi televisi komunitas, 3) Membangun jaringan kerjasama bagi pengembangan televis1 komunitas serta, 4) Membentuk asosiasi televisi komunitas Indonesia.

\section{Pengembangan Sistem Penyiaran}

Pada bagian ini dijelaskan mengenai sistem penyiaran yang akan dikembangkan di Walisongo TV. Sistem penyiaran yang dimaksud di sini adalah serangkaian kerja yang melibatkan berbagai bagian dalam organisasi Walisongo TV mulai dari pembuatan program acara sampai dengan penyiaran/eksekusi program acara tersebut. Proses produksi program telah dijelaskan pada bagian strategi program, karena itu bagian ini tidak akan membahas secara detail langkah-langkah kerja pada bagian produksi. Pembahasan akan lebih dititik beratkan pada proses kerja bagian master control.

Dilihat dari segi cara penayangannya, program acara Walisongo TV dapat dibagi menjadi dua yaitu program live dan program recorded. Program live ditayangkan secara langsung. 
Pengambilan gambar dilakukan secara langsung di tempat kegiatan (bisa di studio ataupun di luar studio). Video dari kegiatan tersebut langsung disiarkan pada saat itu juga tanpa proses pengeditan. Sedangkan untuk program recorded, pengambilan gambar tidak langsung disiarkan pada saat itu, melainkan direkam melalui media perekam (bisa videotape maupun penyimpanan digital). Sebelum disiarkan, program recorded harus melalui proses pengeditan terlebih dahulu. Perbedaan ini menyebabkan perlakuan yang berbeda terhadap keduanya ketika akan disiarkan. Master control bertanggung jawab penuh atas cara penyiaran dari kedua jenis program itu.

Selama masa uji coba sampai dengan saat ini, sistem penyiaran Walisongo TV masih dikontrol secara manual. Penyiaran program acara live dikontrol secara manual oleh master control. Iklan yang disipkan di dalam program acara tersebut direkam ke dalam $\mathrm{CD}$, dan pada saat jeda iklan, master control harus menghidupkan VCD player dan kemudian memindahkan output input video dari kamera ke VCD player. Untuk program acara recorded, acara tersebut juga direkam ke dalam CD. Tentu saja kapasitas penyimpanan CD sangat terbatas, akibatnya diperlukan setidaknya satu CD untuk satu acara. Pada saat terjadi pergantian acara, CD dari acara tersebut juga harus diganti. Belum lagi apabila siaran iklan juga disimpan dalam CD yang berbeda. Bisa jadi diperlukan lebih dari satu VCD player agar siaran tidak terputus. Hal-hal semacam itu tentu saja sangat menyulitkan master control. Tugas yang dia lakukan menjadi sangat berat. Karena itulah perlu dikembangkan sistem penyiaran yang lebih baik untuk menjamin keberlangsungan siaran Walisongo TV.

\section{Tahapan produksi walisongo TV}

Tahapan produksi walisongo TV harus meliputi tahapan : 1) pra produksi, 2) produksi, 3) pasca produksi.

\section{1) Pra Produksi}

Pra produksi adalah salah satu tahap dalam pembuatan sebuah program acara termasuk sinetron/film. Pada tahap ini dilakukan sejumlah persiapan diantaranya adalah meliputi: penulisan naskah skenario, menentukan jadwal pengambilan gambar, mencari lokasi, menyusun anggaran biaya, mencari/mengaudisi calon pemeran, mengurus perizinan, menentukan staf dan kru produksi, mengurus penyewaan peralatan produksi, persiapan produksi, pasca produksi dan persiapan lainnya.

Pra produksi dilakukan dengam melalui sejumlah tahapan diantaranya adalah:

\section{a) Meeting bersama kru Walisongo TV}

Sebelum melakukan aktivitas produksi terlebih dahulu diawali dengan meeting atau diskusi dengan kru secara keseluruhan. Salah satunya dengan Penata Artistik (Art Director). Sutradara membuat sketsa untuk didiskusikan dengan seorang penata artistik. Dari kegiatan diskusi seorang penata artistik akan memberikan masukan serta gagasan yang akan dibangun. Diskusi selanjutnya dengan penata kamera (Director Photography) tentang komposisi, angle, dan camera movement. Bisa juga seorang sutradara mengoperasikan sendiri kamera

b) Penjadwalan shooting (shooting
schedule) 
Sutradara melakukan penjadwalan shooting setelah melakukan breakdown script, dalam hal ini biasanya dibantu oleh assisten sutradara. Ketika asisten sutradara membuat lay out penjadwalan shooting, yang harus diperhatikan adalah halaman naskah yang telah diberi halaman, sehingga sutradara dapat melakukan pengambilan gambar

\section{c) Penetapan ide cerita}

Kemampuan untuk memilih mana yang perlu dan mana yang tidak perlu di rangkai dalam sebuah cerita dibutuhkan suatu kreativitas. Penggalian fakta terhadap skenario yang telah disetting dalam cerita sangat penting dilakukan. Berdasarkan pemahaman dan pengetahuan yang telah ada dikembangkan dengan isuisu dalam kehidupan selama ini. Hal tersebut dapat digali untuk mendapat halhal yang menarik dengan membandingkan fakta yang ada. Penggalian imajinasi terus dikembangkan untuk menyelesaikan suatu permasalahan yang timbul karena benturan nilai-nilai dan kepentingan yang sudah disusun dalam sebuah program.

Sebelum membuat program sebaiknya menentukan tujuan dari program yang akan diproduksi. Apakah sebagai kegiatan dakwah, pendidikan/ pembelajaran, wawasan, dokumenter, hiburan, mengangkat fenomena yang terjadi di masyarakat, atau menyampaikan pesan moral tertentu. Jika tujuan telah ditetapkan, maka semua detail cerita dan pembuatan produksinya akan lebih mudah. Jika perlu melakukan observasi dengan pengumpulan data dan fakta. Bisa juga membaca buku, artikel, atau beranya langsung pada sumbernya. Penggalian ide/imajinasi bisa diperoleh melalui : pengalaman, aktivitas sehari-hari, cerita rakyat/dongeng, biografi seorang yang berhasil, adaptasi cerita fiktif (komik, cepen, novel), kajian-kajian, dan lain sebagainya.

\section{d) Membuat skenario}

Pembuatan produk audio-visual pasti membutuhkan sebuah skenario. Hal ini disebabkan karena produksi dibuat untuk menyampaikan pesan komunikasi secara visual. Ada empat aspek penting yang harus diperhatikan Walisongo TV dalam penulisan skenario, yaitu :

1) konsep cerita, yang dirumuskan dalam sebuah kalimat tunggal yang menjelaskan tokoh atau apa yang ingin diperbuat.

2) karakteristik (perwatakan), yaitu tokoh-tokoh yang terlibat dalam cerita dan setiap tokoh harus dijelaskan karakter dasarnya dengan penjelasan dan penekanan pada tokoh utama. Perbedaan karakter ini akan memainkan peranan penting yang melatar belakangi bagaimana setiap peran bersikap dan berindak untuk menghadapi isu/masalah. Disinilah sekelompok manusia dapat memainkan peran meskipun masing-masing memiliki pikiran/motivasi yang berbeda atau kebetulan sama dengan skenario.

3) alur cerita, bagaimana hubungan kejadian demi kejadian dirangkai menjadi suatu cerita yang akan menentukan keberhasilan terjalinnya produksi cerita yang menarik sehingga dapat membangun emosi pemirsa.

4) rancangan adegan per-adegan, meliputi rangkaian rencana pengambilan gambar yang meliputi dialog, akting, properti, setting lokasi, dan sebagainya 
sehingga dapat dengan mudah dipahami konsep cerita, karakteristik, dan alur cerita yang menarik pada proses produksi

\section{e) Pembuatan storyboard dan layout}

Storyboard adalah rangkaian gambar ilustrasi yang berusaha menjelaskan bahasa tulisan skenario ke dalam bahasa visual. Adegan demi adegan cerita skenario yang sebelumnya telah dirumuskan dalam skenario diterjemahkan menjadi gambar oleh sutradara dengan bantuan cameramen dan storyboard artist. Hal itu dibuat sedemikian rupa, sehingga dalam potongan-potongan ilustrasi yang dihasilkan terhimpun informasi tentang para pelaku adegan, adegan yang dilakukan, lokasi dan properti, sudut pengambilan gambar, dan sebagainya.

Layout, yaitu bentuk lanjutan dan terakhir kegiatan pra-produksi. Di sini, gambar-gambar story-board dirangkai dalam suatu kegiatan editing video, sesuai skenario. Elemen lain bisa ditambahkan, misalnya dubbing narasi dan musik ilustrasi. Hasil akhirnya berupa file video yang dapat disaksikan bersama oleh kru produksi dan klien.

Manfaat layout ini adalah : 1) kru produksi mendapat gambaran yang jelas tentang produk yang akan dihasilkan, 2) "Pace" dari video dapat terasa. Idealnya menyampaikan pesan/informasi yang berkembang setiap saat dengan kecepatan yang tepat, 3) peran ilustrasi musik terhadap pembentukan mood video dapat terasa, dan editor dapat bereksperimen dengan backsong yang akan digunakan, 4) secara teknis membantu editor saat mengedit video. Hal itu disebabkan karena potongan gambar ilustrasi tersebut sudah diatur tempat dan durasinya sehingga hanya tinggal diganti dengan hasil shooting video, 5) secara mental kru produksi akan merasa bahwa "video sudah hampi selesai" dan tinggal mengisi potongan-potongan gambar ilustrasi dengan hasil shooting video.

\section{2) Produksi}

Walisongo TV dalam melakukan kegiatan produksi atau bisa disebut juga shooting video harus dilakukan dengan tuntas sesuai dengan kebutuhan tahap pra produksi. Agar gambarnya bisa ideal dalam bentuk story-board yang mencakup banyak informasi termasuk sudut pengambilan gambar (angel), maka kegiatan produksi sebaiknya melalui beberapa tahapan yaitu:

\section{a. Mengelola pelaksanaan produksi}

Seorang produser dalam memproduksi sebuah acara perlu menunjuk pembantu-pembantunya untuk membantu menangani pekerjaan produksi. Berbagai macam jenis program tentu membutuhkan keahlian yang bermacam-macam. Oleh karena itu perlu dibentuk organisasi produksi. Satu produksi program TV melibatkan banyak orang, misalnya artis, crew, host, nara sumber, bahkan kadang membutuhkan aparat keamanan dan pejabat yang terkait dengan perijinan. Produser pelaksana mengkoordinir bendahara dan juru bayar, kesekretariatan yang mengurus surat menyurat dan perijinan.

Organisasi lapangan diserahkan kepada unit manajer yang bekerjasama dengan artistik dan kesekretariatan yang berada di bawah sutradara. Bidang yang langsung dibawah unit manajer adalah perizinan, transportasi, konsumsi, dan akomodasi. Sutradara merupakan orang 
yang bertanggungjawab penuh dalam kegiatan produksi dan bertanggungjawab kepada produser. Dalam bekerja dibantu oleh art director, kameramen, penata cahaya serta penata sound. Sutradara juga dikenal dengan directing yaitu mengarahkan para tenaga kerja produksi program agar berjalan dengan lancar dan berhasil.

b. Direktur.

Sebagai pengarah yang membantu produser. Untuk itu dibutuhkan seseorang sutradara yang memiliki kemampuan manajerial yang baik. Sutradara harus selalu berkoordinasi dengan produser dalam melaksanakan tugasnya untuk kelancaran shooting. Diantaranya bagaimana menerjemahkan naskah menjadi naskah yang dapat diproduksi, melaksanakan seleksi aktor/pemain, mengarahkan proses shooting, menentukan cakupan kamera dan sudut pengambilan gambar

c. Rancangan panggung/bangunan

Rancangan bangunan untuk keperluan pengambilan gambar serta dekorasi harus mampu membuat suasa ruang yang mendukung dan mempertegas latar peristiwa sehingga mampu mengantarkan alur cerita yang menarik. Dalam bekerja harus bekerjasama dengan perancang kostum untuk memastikan kosntum pemain atau lokasi/latar belakang sudah sesuai keinginan alur cerita atau belum.

\section{d. Soundman}

Soundman bertugas mengoperasikan alat perekam audio yang harus berjalan secara sinkron dengan kamera . Dalam mengatur pekerjaannya, teknisi audio mixer harus merekam sinyal audio secara konsisten dan seimbang agar menghasilkan rekaman yang mulus. Pada produksi program siaran televisi, teknisi audio duduk dibelakang konsol audio mixer yang menjadi bagian ruang master control dimana soundman mengontrol suara yang berasal dari berbagai sumber suara. Jenis mikrofon yang digunakan harus berkualitas sehingga menghasilkan suara yang baik. Mudah dibawa, peka terhadap sumber suara, dan mampu meredam gangguan suara di dalam dan di luar ruangan.

e. Lighting

Penataan cahaya dalam produksi siaran sangat menentukan bagus tidaknya kualitas hasil produksi. Untuk menghasilkan cahaya yang bagus kamera video yang dugunakan harus memperhatikan perbandingan bagian ruang yang paling terang (Hi light) dan bagian yang tergelap (shade) agar tidak terlalu tingi atau kontras. Lebih baik sesuai dengan petunjuk lighting yang disarankan.

\section{f. Casting talent}

Untuk memenuhi keinginan produser berdasarkan naskah yang akan diproduksi, sutradara menentukan waktu shooting. Selanjutnya menentukan pemain yang memiliki talenta sesuai dengan peran dalam naskah. Bisa berdasarkan fisik, berat badan, bentu tubuh, watak, kemampuan untuk memainkan peran atau berdasarkan pengalaman dari observasi hidup pribadinya yang kebetulan memiliki banyak kemiripan dengan naskah. Perlu diperhatikan juga maslah kostum dan tata rias tidak hanya pada wajah tetapi mencakup seluruh badan yang berpatokan pada skenario. Unsur manipulasi sangat berperan pada teknik tata rias dan kostum, hal itu disesuaikan juga dengan bagaimana efeknya pada saat pengambilan gambar dengan kamera. Membuat tampak 
cantik, tua, sakit, jahat/ baik, dan sebagainya.

g. Cameraman

Seorang kameraman bertugas untuk mengoperasionalkan video kamera untuk recording. Memiliki hak untuk mengambil gambar secara pribadi sebagai stok gambar. Untuk itu dibutuhkan kameraman yang handal, memiliki kemampuan yang berhubungan dengan kamera. Ada beberapa syarat untuk menjadi kameraman yang handal diantaranya yaitu :1) mempunyai naluri yang tinggi dalam menentukan pengambilan gambar yang bernilai estetika, 2) dapat mengatur kuantitas cahaya saat pengambilan gambar, 3) menguasai teknik pengambilan gambar, 4) menguasai isi skenario, 5) tidak gugup/grogi saat pengambilan gambar dengan seluruh obyek yang besar maupun yang kecil baik dari atas, samping kiri kanan, atau dari bawah. Yang jelas memahami cara pengambilaan gambar dari sudut panjang dan lebarnya juga dari pergeseran kameranya baik yang bergerak maupun diam di tempat.

h. Switcherman

Pemandu gambar (switcherman) adalah orang yang bertugas menampilkan perpaduan gambar dari beberapa sumber gambar ke dalam satu tampilan visual program televisi, sehingga memiliki estetika. Setiap produksi siaran televisi bertugas mengoperasionalkan peralatan switcher yang berfungsi untuk memindahkan satu gambar ke sumber gambar lainnya atas perintah program director. Pada produksi program siaran bertugas mengawasi seluruh kru teknik untuk meneruskan perintah program director kepada kameraman sementara dia tetap mengoperasikan peralatan switchernya.

\section{i. Scriptwriter}

Penulis naskah sangat diperlukan pada saat proses produksi. Sebagai dasarnya adalah berfikir dalam gambar. Penulisannya melalui dua tahap yaitu tahap visualisasi dan tahap pikturisasi. Visualisasi adalah ungkapan dari gambar demi gambar yang ada di dalam benak penulis naskah, misalnya anak kecil yang jelek dan nakal, atau wanita cantik baik hati. Apa yang akan divisualisasikan dengan kenakalan dan kecantikan tersebut. Gambar-gambar yang divisualisasikaan sebenarnya masih sendiri-sendiri, penulis naskah harus merangkai gambar demi gambar sehingga membentuk makan. Hal tersebut yang disebut pikturisasi

j. Penyusunan naskah

Tahap-tahap penyusunan naskah, meliputi :

1) Ide, Untuk menulis naskah sangat membutuhkan ide. Tiap orang memiliki cara yang berbeda untuk memunculkan ide. Ada yang cukup berkhayal, melakukan penelitian/observasi, atau dengan berkhayal dilanjutkan melakukan penelitian. Karena jika ide sudah muncul, maka bisa mulai menentukan tema dan tujuan dari cerita.

2) Sinopsis, ringkasan cerita atau sinopsis di buat untuk memudahkan mengingat atau menjaga naskah agar tidak keluar dari tema dan tujuan cerita.

3) Treatment, dilaksanakan setelah sinopsis jadi. Harus ada keterangan karakter, sifat-sifat dan ciri, juga keterangan identitas lokasi dan property yang digunakan 
4) Naskah/ script, dibuat menggunakan panduan dari treatmen. Untuk membuat harus ada keterangan secara detail tentang alur cerita, adegan, angle, dialog, identitas lokasi dan suasana adegan juga musik pengiringnya.

\section{3) Pasca Produksi}

Untuk menghasilkan produksi yang berkualitas pasti melakukan editing. Sesuai dengan peralatannya proses editing ada dua macam, yaitu editing analog dan digital atau nonlinier dengan perangkat komputer editing. Tujuan dari editing adalah agar nilai dramatisnya memiliki seni dan daya tarik bagi pemirsa. Selain itu juga untuk kontinuitas atau kesinambungan cerita. Pasca produksi yang dilakukan Walisongo TV meliputi beberapa langkah langkah yaitu:

a. Editing Off Line Digital (non linier)

Pada prinsipnya editing off line digital prosesnya sama dengan analog, hanya untuk editing digital menggunakan bantuan peralatan komputer editing yang memiliki fasilitas editing seperti penecle studio, matrox, canupus dengan program aplikasi jga bermacam-macam seperti adobe premier, yulied, three D Max, After Effect dan sebaganya. Juga program animasi grafis yang bermacam-macam pula. Semua itu akan memudahkan pekerjaan seorang editor dan biasanya editor akan menggunakan berbagai program sesuai dengan kebutuhannya.

Kesulitan editing analog adalah menyambung antara shot yang satu dengan yang lain, yang apabila tidak cermat maka akan kelihatan jumping. Dalam proses digital pada setiap sambungan tinggal menambahi program transisi yang sudah tersedia secara instant tinggal pilih jenisnya.

Tahap pertama yang dilakukan adalah capturing/digitalisasi hasil shoting yang masih analog di-capture melalui capture card diubah menjadi file data digital lalu bisa disimpan dalam harddisk dan setiap saat bisa dipanggil kembali apabila diperlukan.

Tahap kedua editing off line adalah menyusun hasil shot sesuai dengan keingingan/gagasn sutradara sesuai sinopsis dan treatment. Urutan penyusunan tidak harus seperti editing analog karena komputer bisa mulai dari mana saja, baik dari tengah, akhir maupun dari awal. File yang cukup besar bisa dipecah-pecah menjadi beberapa file, sehingga bisa lebih terkonsentrasi. Setelah dirutkan menjadi satu lalu ditambah efek transisi pada setiap sambungan selanjutnya di-render untuk fixing file. Setelah proses itu, file dapat dilihat secara utuh dan dapat dilakukan screening untuk cek ulang bila mungkin ada kekurangan/ kesalahan bisa disempurnakan. Setelah semua memuaskan maka editing off line selesai dan siap dilakukan editing on line.

\section{b. Editing On Line Digital (non linier)}

Tahap ini merupakan kelanjutan editing off line yang dilakukan editor dengan program komputer, yaitu menyempurnakan hasil editing off line, memasukkan dan menata suara asli, ilustrasi musik, sound efek ke dalam file gambar pada track yang berbeda-beda sehingga gambar yang sudah ditata tidak akan ternganggu. Setelah hasilnya sempurna dan memuaskan, selanjutnya dilakukan pengubahan format yang sesuai dengan player yang akan digunakan (VCD, DVD, Video dan sebagainya). 
Dalam produksi program televisidurasi harus disesuaikan dengan format waktu atau frame/slot yang sudah ditetapkan, yaitu 30 menit atau 60 menit sudah termasuk iklan komersial/layanan masyarakat. Untuk slot30 menit durasi efektif adalah 24 menit. Untuk slot 60 menit durasi efektif 48 menit dan sisanya disediakan untuk iklan (commersial break). Hal ini penting supaya tidak ada pemotongan program sewaktu diadakan penyiaran program.

Di dalam proses logging semua hasil shoting telah diberi tanda (time code) yaitu nomor kode berupa digit frame, detik, menit dan jam dimunculkan dalam gambar. Hasil pengambilan setiap shot telah dicatat oleh scriptman/girl. Berdasarkan catatan tersebut, sutradara akan melakukan editing off line yaitu editing kasar dan copy video VHS sesuai dengan gagasan dalam synopsis dan treatmen. Materi shoting langsung dipilih dan disambung-sambung dalam piha VHS. Setelah selesai lalu hasilnya dilihat secara sermat dalam screening. Apabila masih belum meuaskan perlu ditambah atau diedit lagi sampai hasilnya memuaskan.

Setelah editing off line selesai dilanjutkan dengan pekerjaan editing script atau naskah editing yang didalamnya sudah dilengkapi dengan narasi, ilustrasi musik. Format naskah editing sama dengan format naskah scenario, tetapi sudah dilengkapi dengan logging untuk mempermudah editor melakukan editing. Selanjutnya hasil shoting asli dan naskah editing diserahkan kepada editor untuk dilakukan editing on line menggunakan pita betacam yaitu yang memiliki kualitas standard broadcast. Pita VHS hasil editing off line digunakan editor sebagai panduan editing on line.

\section{c. Mixing}

Mixing adalah pencampuran antara gambar dan suara. Narasi yang sudah direkam dan ilustrasi musik yang juga sudah direkam lalu dimasukkan ke dalam pita hasil editing on line sesuai dengan petunjuk yang ada dalam naskah editing. Keseimbangan antara suara asli, narasi, ilustrasi musik dan sound efek menjadi perhatian utama agar serasi dan harmonis dan terdengan dengan jelas. Setelah proses mixing selesai maka proses produksi sudah selesai dan tinggal mengadakan preview yang apabila mungkin ada saransaran perbaikan. Selanjutnya program siap ditayangkan.disiarkan ke publik,

\section{Analisis Manajemen Strategis dan Program Siaran Walisongo TV}

Perencanaan program pada umumnya menjadi tanggungjawab manajer program. Proses kerjanya bekerjasama dengan manajer pemasaran dan umum. Program merupakan unsur penting untuk menarik audien, sehingga perlu perencanaan yang matang agar memiliki kualitas daya tarik pemirsa untuk menikmatinya. Pengelola program stasiun televisi harus mampu mengarahkan programnya kepada segmen audien tertentu yang tersedia dalam program siar.

Dalam merencanakan dan memilih program, bagian program harus berkonsultasi dan bekerjasama dengan bagian pemasaran untuk memasarkan program kepada pemasang iklan. Bagian program memiliki pemirsa, sedangkan bagian pemasaran menjual pemirsa kepada para pemasang iklan. Ketika bagian program merencanakan untuk membeli satu paket 
sinetron atau film misalnya, maka bagian pemasaran harus terlibat pembahasannya. Hal itu diperlukan untuk mendapat masukan dari bagian pemasaran mengenai prospek penjualan program kepada pemasang iklan.

Merencanakan dan memilih program merupakan keputusan bersama antara departemen program dan departemen pemasaran. Bagian program harus mampu melakukan penelitian terhadap selera audien sebelum membeli suatu program. Harga program yang sukses pada umumnya cukup mahal, namun harus disesuaikan dengan selera pemirsa. Satu acara yang sukses di satu daerah misalnya pasti sukses di daerah lain.

Pengelola program siaran yang baik harus mengetahui acara apa yang menarik untuk kelompok-kelompok yang berbeda di kalangan masyarakat, misalnya apa yang sedang populer dan digandrungi, serta menarik di kalangan anak-anak, remaja, dan dewasa. Mainan apa yang menarik dan populer di kalangan anakanak usia pra sekolah usia 2-6 tahun, hal permainan apa yang sedang menjadi perhatian anak-anak usia sekolah $6-12$ tahun, busana atau kegiatan apa yang sedang dilakukan remaja usia 12-15 tahun, 15-18 tahun, 18-21 tahun, apa yang menarik bagi orang dewasa dini usia 2140 Tahun, apa yang menarik bagi orang dewasa madya usia 40 - 60 th sampai usia lanjut usia 60 th.

Faktor lain yang perlu dipertimbangkan dalam merencanakan program baru yang akan disiarkan sebelum program diproduksi adalah melakukan akuisisi dilanjutkan skeduling terhadap suatu program yaitu : persaingan, dan ketersediaan audien. Selain itu juga harus melihat program apa yang ditayangkan televisi saingan lainnya pada saat/jam yang sama. Sehingga pengelola program bisa mempertimbangkan apakah program baru tersebut cukup kuat untuk menarik audien dari stasiun saingan untuk pindah ke stasiun sendiri. Jika kuat menarik audien, maka program baru tersebut bisa ditayangkan, tetapi jika tidak sebaiknya mencari jam tayang lain yang tepat untuk disiarkan. Untuk acara program serial bagian program harus merencanakan berapa kali satu minggu akan ditayangkan, setiap hari, dua hari sekali, atau berapa hari sekali. Usahakan mampu membentuk kebiasaan audien untuk menonton program secara rutin dalam mendorong keberhasilan suatu program. Di samping itu harus diketahui pula siapa audien yang menonton acara televisi pada waktu-waktu tertentu sehingga pemasangan iklan juga bisa tepat sasaran.

\section{Analisis dan strategi program walisongo TV}

Perencanaan program Walisongo TV pada dasarnya bertujuan memproduksi atau membeli program yang akan disiarkan dan ditawarkan kepada pasar audien. Agar program penyiarannya berhasil maka harus memiliki rencana pemasaran yang strategis sebagai pedoman untuk menggunakan sumber daya yang ada secara maksimal.

Rencana strategis untuk memasarkan program sebaiknya ditentukan berdasarkan analisis situasi mengenai kondisi pasar audien yang ada. Segmentasi audien dan tingkat persaingan yang ada harus diperhatikan agar kebutuhan audien bisa terpenuhi dan memberikan peluang untuk menerima dan menikmati program penyiaran. 
Hal yang harus dilakukan adalah menganalisis peluang dan analisis kompetitif. Analisis peluang secara cermat terhadap pasar audien untuk menerima dan memberikan peluang terhadap acara yang disiarkan sehingga timbul kepuasan dan keinginan untuk selalu menikmati. Analisis peluang selanjutnya adalah peluang pasar yang merupakan wilayah dimana terdapat kecenderungan permintaan terhadap program yang menguntungkan bagi audien yang hiterogin, sehingga memberikan kepuasan dan bisa bersaing secara kompetitif dengan stasiun lain.

Analisis kompetitif dilakukan untuk mempersiapkan strategi dan rencana program terhadap persaingan stasiun penyiaran dan persaingan program yang ada pada segmen pasar audien baik secara langsung (program yang dimiliki sendiri) maupun tidak langsung (media non penyiaran). Hal ini dilakukan agar stasiun penyiaran mampu memberikan keuntungan dan mampu bersaing dengan stasiun televisi yang lain. Diharapkan lebih produktif menghasilkan program yang berkualitas dengan biaya rendah sehingga harga program menjadi murah. Kegiatan untuk memperhatikan dan melakukan analisis kompetitif harus dilakukan secara terus menerus agar memberikan dampak yang positif bagi strategi program sehingga mampu bersaing dan selalu mendapatkan perhatian audien.

\section{Pengawasan dan Evaluasi Program}

Melalui perencanaan, stasiun televisi menetapkan rencana dan tujuan yang ingin dicapai. Proses pengawasan dan evaluasi menentukan seberapa jauh suatu rencana dan tujuan sudah dapat dicapai atau diwujudkan oleh stasiun penyiaran, departemen dan karyawan. Kegiatan evaluasi secara periodik terhadap masingmasing individu dan dpartemen memungkinkan manajer umum membandingkan kinerja sebenarnya dengan kinerja yang direncanakan. Jika kedua kinerja tersebut tidak sama maka diperlukan langkah-langkah perbaikan.

Pengawasan harus dilakukan berdasarkan hasil kerja atau kinerja yang dapat diukur agar fungsi pengawasan dapat berjalan secara efektif. Misalnya jumlah dan komposisi audien yang menonton yang diukur dan diketahui melalui laporan riset rating. Jika jumlah audien yang tertarik dan mengikuti program lebih rendah dari yang ditargetkan, maka proses pengawasan mencakup kegiatan pengenalan terhadap masalah dan memberikan pengarahan untuk dilakukan diskusi agar mendapat solusi. Hasil diskusi dapat berupa perubahan rencana misalnya revisi legih rendan dari ekspektasi sebelumnya atau tindakan lain yang akan dilakukan untuk dapat mencapai target semula.

\section{PENUTUP}

1. Dalam mengembangan program siaran Walisongo TV perlu perencanaan dengan matang agar memiliki kualitas daya tarik pemirsa untuk menikmatinya. Pengelola program stasiun televisi harus mampu mengarahkan programnya kepada segmen audien tertentu yang tersedia dalam program siarnya.

2. Manajeman modern siaran televisi merupakan kebutuhan mutlak, karena semua aktivitas dalam mempersiapkan dan memproduksi siaran tidak bisa lepas dari teknologi komputer. 
komputer mempunyai pengaruh yang sangat besar dalam mempercepat menghasilkan sebuah produk, dengan perangkat komputer program siaran dapat tersusun sesuai dengan waktu siar yang diinginkan.

3. Sistem informasi manajeman walisongo TV berupa website merupakan kebutuhan yang tidak bisa dilepaskan karena merupakan bagian dari pengembangan stasiun televisi, sehingga informasi tentang walisongo TV dan program siaran dapat cepat sampai kemasyarakat luas.

\section{DAFTAR PUSTAKA}

Jalaludin Rakhmad, Metode Penelitian Komunikasi, PT. Remaja Rosdakarya, Bandung, 1984

Djuarsa Sendjaja, Turnomo Raharjo, Teori Komunikasi antara Pribadi Dimensi-Dimensi Pribadi dan relasional, modul Teori Komunikasi, Pusat Penerbitan Universitas Terbuka, 2002.

Morissan, Jurnalistik Televisi Mutakhir, Ghalia Indonesia, Jakarta 2003.

Joseph R. Dominick, The Dynamics of Mass Communiication, Media in the Digital Age, Seventh Edition, McGraw-Hill, Boston, 2002

Longman, The Dictionary of Contemporary English, Perason Education Limited, Essex, England, 2003.
Peter K. Pringle, Michael F. starr, William E. McCavitt, Electronic Media Managemen (Second edition), Focal Press, Boston-London, 1991.

James AF. Stoner, Management, Edisi Kedua, Prentice-Hall International, Inc., Englewood Cliffs, New York, 1981.

Ulber Silalahi, Pemahaman Praktis AsasAsas manajemen, (Bandung: Mandar maju, 2002)

Agus Sudibyo, Ekonomi Politik Media Penyiaran, (Yogyakarta: LkiS, 2004).

Ashadi Siregar, Menyingkap Media Penyiaran : Membaca Televisi Melihat Radio, (Yogyakarta : Lembaga Penelitian Pendidikan Penerbitan Yogya (LP3Y), 2001).

Darwanto Sastro Subroto, Televisi Sebagai Media Pendidikan, (Yogyakarta : Pustaka Pelajar, 2007).

Indah Rahmawati dan Dodoy Rusnandi, Berkarier di Dunia Broadcast Televisi dan Radio, Bekasi-Jawa Barat, Laskar Aksara, 2008.

Morissan, M.A., Manajemen Media Penyiaran : Strategi Mengelola radio dan Televisi, Edisi Pertama, Jakarta : Kencana 2008. 